\title{
Difference in the patterns of food consumption of rural households in Bangladesh
}

$\bowtie$ Mahbub Hossain

Department of Agricultural Economics, Bangladesh Agricultural University, Mymensingh-2202, Bangladesh

\begin{tabular}{l}
\hline ARTICLE INFO OPEN ${ }_{\text {Access }}$ \\
\hline Article history: \\
Received : 07 January 2019 \\
Accepted : 14 May 2019 \\
Published: 30 June 2019 \\
\hline
\end{tabular}

Keywords:

Food consumption pattern, rural households, Bangladesh

Correspondence:

Mahbub Hossain

凶: mahbub@bau.edu.bd

\begin{abstract}
Food consumption pattern hints the proportion of various foods that households consume to meet their nutritional requirements, which is crucial to know from the policy perspective. While several studies have documented a strong link between household dietary diversity and nutritional status of household members, especially of children; the evidence that whether or not the proportions of households' intake of nutrients from different foods differ across the income levels is almost nonexistent. The present study fills in this void in the literature by generating evidence on variations in the consumption pattern with income in the context of a low middle-income country. By using data from a national level rural households survey, this paper finds that food consumption pattern significantly differs across income classes and notably with a rise in income households tend to substitute less nutritious food with more nutritious food. However it is found that carbohydrates dominate the rural households' diets with few proteins, vitamins, and minerals. Hence as far as food security is concerned, policymakers need to emphasise on policies that would promote households' behavioural change in respect of food choices. Less income inequality in the economy may also be conducive to improve national food security.
\end{abstract}

Copyright:

(c) (i)

(2019 by authors and BAURES. This work is licensed under the Creative Commons Attribution International License (CC By 4.0).

\section{Introduction}

Few topics other than food and nutrition security are of great importance to human survival and development (Mishra \& Ray, 2009). In the same way improving nutrition is a priority for the Government of Bangladesh, which is the country's constitutional duty as well (HKI \& JPGSPH, 2014). Although the national level poverty in the country has fallen to the targeted level of the MDGs (GoB, 2015), still one-third of the Bangladeshi under-five children suffer from moderate to severe under-nutrition (NIPORT, Mitra and Associates, \& ICF International, 2016). The incidence of child malnutrition is considered to have a close link with household food insecurity. For example, Saha et al. (2009) reported that the proportion of underweight children is the lowest in the food secure households and the other way around. While food security and nutrition can be thought of as improving when the income of people and availability of food increases, it is puzzling that under-nutrition and food insecurity in Bangladesh continues despite a long spell of the country's stable economic growth of over 6 percent $(\mathrm{GoB}, 2017)$.

The association of income and food security in Bangladesh has found to be positive, as by using data from three districts of Bangladesh, Harris-Fry et al. (2015) have found that wealthy households tend to have diversified foods. There is also evidence that when households' dietary diversity increases food consumption and calorie intake rises i.e. nutritional security of household members increases (Hoddinott \&

Hossain, M. 2019. Difference in the patterns of food consumption of rural households in Bangladesh. Journal of Bangladesh Agricultural University, 17(2): 232-235. https://doi.org/10.3329/jbau.v17i2.41987

Yohannes, 2002) cited in (Mishra \& Ray, 2009). Zongrone, Winskell, and Menon (2012), who have analysed a country level dataset of Bangladesh Demographic and Health Survey, have shown that the chance of improved nutritional status among children increases significantly with the rise in variation in household dietary diversity. A similar finding is reported in another study on Bangladesh by Rah et al. (2010) and Arsenault et al. (2013). However Hossain, Naher, and Shahabuddin (2005) have shown that households diets lack in variation in Bangladesh and the major share of a Bangladeshi household's diet comes from cereals. Such a link between dietary diversity and nutritional indicator of children prompts concerns around the pattern of food consumption of Bangladeshi households, especially in the rural regions of the country where the incidence of child under-nutrition is considerably high. An investigation of the food consumption pattern may give a hint at whether the incidence of high under-nutrition can be attributed to the composition of households' diet. Notably in the literature there are not many studies that have looked at the Bangladeshi rural households' food consumption pattern perhaps owing to the lack of the disaggregated food consumption data at the countrylevel. As a result, there is a dearth of evidence on whether rural Bangladeshi households' food consumption patterns vary because of income. In order to fill in such void in the literature, this study aims to investigate the above research question in the context of rural Bangladesh. 


\section{Materials and Methods}

The data for this study comes from the Bangladesh Integrated Households Survey (BIHS) 2012. This survey - representative of all administrative divisions of Bangladesh-has interviewed 6,503 rural households across Bangladesh. The BIHS is a very rich dataset from the standpoint of food consumption data, which has been conducted in periods that do not coincide with the country's any lean seasons.

The BIHS contains data on the quantity of various food consumed by households in a normal day, which gives information on the total quantity of food a household consumes. Dividing these quantities by the household size gives the per capita availability of food. Since foodwise disaggregated data are available in the BIHS, it becomes possible to compute the share of various food groups on per capita food availability. The broad categories of food considered in this study include: (i) cereals, (ii) pulses, (iii) vegetables, (iv) fish, (v) meat, (vi) oils or fats, and (vii) fruits.

The share of the above food groups gives the food consumption pattern of the sample households. Since one of the objectives of this study is to investigate whether the households have similar food consumption pattern across income classes, the sample is split into four quartiles on the basis of per capita monthly expenditures. Monthly expenditure is considered here as a proxy of income because literature suggests expenditure data gives a better reflection of households' permanent income. It may be noteworthy that the bottom quartile represents the poorest; while the richest belong to the top quartile. The food consumption pattern is obtained for each quartile using respective households' data.

In order to explore whether the households consume various food in the same proportion, analysis of variance (ANOVA) technique is used in this study. The method is appropriate because the objective here is to compare the mean of the share of food groups across households' level of income. The null hypothesis is that the mean share of food group does not differ across income classes; while the alternative hypothesis is the share does vary.

Let $X_{i j}$ is the share of food-X on household-i's daily per capita food availability in income quartile $\mathrm{j}$. Where $\mathrm{i}=1$, . . ., 1626 (households), and $\mathrm{j}=1, \ldots, 4$ (quartiles). The overall sample mean share of a food group, say cereals, is $\bar{X}$, and the mean share of cereals on per capita food availability of households in quartile 1 is $\bar{X}_{1}$. Thus between sum of squares (SSB) in the case of cereal is $S S B=\sum r\left(\bar{X}_{j}-\bar{X}\right)^{2}$ and the within sum of squares is $S S W=\sum \sum\left(X_{i j}-\bar{X}_{j}\right)^{2}$. Here r stands for the number of households in the quartile-j. The degree of freedom of SSB and SSW is (k-1) and (N-k), respectively where $\mathrm{k}$ is the number of total quartiles. The ANOVA technique requires comparing SSB and SSW, which follows an F-distribution. Mathematically it can be written as follows

$$
F=\frac{S S B /(k-1)}{S S W /(N-k)}
$$

If the calculated F-value exceeds the critical value of $F$ at 5 or 1 percent level of significance then the null hypothesis - mean share of a food group (e.g., cereals) on daily food availability does not differ across income classes-will be rejected. This ANOVA procedure will be repeated for the rest of the food groups as well.

\section{Results and Discussion}

This section presents the results of the study and provides a discussion of the results. Table 1 shows the share of various food groups on the entire sample households' per capita daily food availability. It is to be noted here that these shares add up to 100 .

Table 1. Food group share (percent) on overall sample households' per capita daily food availability

\begin{tabular}{lcc}
\hline Food groups & Share (percent) & Standard deviation \\
\hline Cereals & 53.812 & 10.773 \\
Pulses & 1.194 & 2.855 \\
Vegetables & 33.191 & 11.681 \\
Meat & 2.229 & 5.854 \\
Fish & 6.638 & 6.617 \\
Oils/fats & 2.039 & 1.496 \\
Fruits & 0.894 & 3.295 \\
\hline
\end{tabular}

Source: Author's calculation from the BIHS data

It is evident from Table 1 that the largest share of the sample households' diet comes from cereals (about 54 percent) followed by vegetables (33 percent). This finding is consistent with what the Bangladesh Household Income and Expenditures Survey has highlighted. As can be seen households prefer cereals more than any other food for fulfilling their dietary needs. It implies that more than half of total available food comprises cereals in rural households' diet. This is so primarily because cereals - rice in particular-is the staple food in Bangladesh. According to the latest HIES, average per capita cereal consumption is about $486 \mathrm{gm}$ in rural areas of the country (BBS, 2011).

The food group that contributes the second largest share of diets is vegetables, which is about one-third of total food availability. What is impressive about it is that having had vegetables in one-third proportion increases the likeliness of households' intake of vitamins, minerals, and other micronutrients. This is thus a very good sign from the food security perspective. Apart from demand factor, there may be supply-side factor in operation as well. For instance, growing vegetables in 
homestead and backyard are becoming common among rural households, which may have resulted in households' increased consumption of vegetables (Bose $\&$ Dey, 2007). Turning to another very important food group-fruits, we can see that it is almost absent in rural households' diets as its share is less than 1 percent. While it is recommended that at least $100 \mathrm{gm}$ of fruits should be consumed daily by an adult (Nahar, 2013); the average fruits consumption in rural areas is about $43 \mathrm{gm}$ (BBS, 2011). This implies that the inadequacy in fruits consumption may increase the risk that household members' requirement of micronutrient remains unfulfilled.

Protein is vital for maintaining good health for a variety of reasons: growth of human body and prevention of decay (Ahmed, Barnett, \& Longhurst, 2015). Animalbased source of protein includes fish and meat whereas plant-based protein comes from pulses. It can be seen that about one-tenth of available food is sourced from pulses, fishes, or meat. A further concern is how frequent households consume protein-rich food, however this cannot be understood from merely the shares. The low relative share of protein on households' diet is so perhaps because protein is a costly food for households to consume. Since protein is an essential macronutrient, any decline in its consumption would create public health concern in the country.

Now Table 2 shows the comparison of the mean share of various food groups by income classes. As mentioned earlier, the whole BIHS sample is split into four quartiles based on income and for each quartile the mean share of food is computed in Table 2 .

Table 2. Mean share (percent) of food group by income class

\begin{tabular}{lccccccc}
\hline \multicolumn{1}{c}{ Income class } & Cereals & Pulses & Vegetables & Meat & Fish & Oils & Fruits \\
\hline Poorest & 56.204 & 1.003 & 34.161 & 1.042 & 5.105 & 1.844 & 0.638 \\
Lower middle & 54.863 & 1.062 & 33.012 & 1.812 & 6.387 & 1.915 & 0.946 \\
Upper middle & 53.526 & 1.219 & 33.209 & 2.400 & 6.797 & 2.034 & 0.813 \\
Richest & 50.653 & 1.491 & 32.383 & 3.662 & 8.265 & 2.363 & 1.179 \\
All & 53.812 & 1.194 & 33.191 & 2.229 & 6.638 & 2.039 & 0.894 \\
\hline
\end{tabular}

Source: Author's calculation

There are several striking features in Table 2. First, the share of cereals on daily food availability falls as income rises. There is almost a 6.5 percent point difference in the share of cereals between the poorest and the richest. This may reflect that as income rises households' preference for cereals tends to decrease.

Second, with regard to consumption of meat, fish, and pulses there is an increasing pattern with the rise of income level. Furthermore a big difference can be noted in their share between the poorest and the richest. There is about $0.5,2.6$, and 3.1 percent point difference in the mean share of pulses, meat, and fish respectively between the poorest and the richest. This may be suggestive of changes in households' preference for food with income level. Table 2 suggests that households tend to substitute low nutritious food (e.g., cereals) with high nutritious (e.g., protein-rich) food as income rises.

Third, the share of other food groups except vegetables rises as income increases. In the case of vegetables there is no such unidirectional pattern of change in shares across the income quartiles. While the richest seem to prefer vegetables less than what the poorest do; upper middle-class households prefer vegetables slightly more than what the lower middle-class households do.

On the basis of the result presented in Table 2, it can be said that food consumption pattern of rural households does differ with respect to income. Now let us examine whether or not the observed variation in the mean share of food groups across income quartiles is statistically significant.
Table 3 summarises the ANOVA results for all 7 food groups considered in this study. The Table also reports p-value to indicate the level of significance. As can be seen from the Table, the calculated $F$ value is large for all food groups implying that the test is statistically highly significant, confirmed by the very small $\mathrm{p}$-value (level of significance is even less than 1 percent). Thus, the null hypothesis of no difference in the mean share of food groups across income classes can be rejected. Therefore, we can infer from the results that the food consumption pattern is different for households belonging to different income levels. With the rise of income, households tend to substitute low nutritious food with nutrient-rich foods.

Table 3. One-way ANOVA for the share of various food groups by income class

\begin{tabular}{lcc}
\hline Food groups & Calculated F-value & $\mathrm{p}$-value \\
\hline Cereals & 81.76 & 0.000 \\
Pulses & 9.53 & 0.000 \\
Vegetables & 6.48 & 0.000 \\
Meat & 59.52 & 0.000 \\
Fish & 64.75 & 0.000 \\
Oils/fats & 39.06 & 0.000 \\
Fruits & 7.83 & 0.000 \\
\hline
\end{tabular}

Source: Author's calculation

\section{Conclusion and policy implication}

Based on the empirical findings of the study, it becomes evident that rural households' food consumption pattern lacks in diversity. Moreover rural households' diets are over-dependent on low nutritious carbohydrate-rich foods. Cereals, as expected, constitute the lion share of 
rural households' daily diets in rural Bangladesh. Despite whatever decrease in the share of cereals is found across income classes; cereals still hold the major share in rural households' diets. This implies that households tend to rely on excessive carbohydrate consumption for attaining their required calories. The policy concern is that merely cereals can hardly fulfil the requirements of other nutrients such as proteins, vitamins, and minerals. A further concern stemming from the over-dependence on cereals is that any rise in the price of cereals would affect almost all the rural households' food security in Bangladesh; in particular, the poorest would be the hardest-hit. The extent of such an impact would spread over all rural households because it is the staple food of all. The policy implication of this would be that the national planners who are working to improve the food security should emphasise policies towards diversifying food consumption pattern. Policymakers should also bear in mind that it would be imperative to keep the price of nutrient-rich foods within the purchasing capacity of the rural people.

Since inequality in nutrient-rich food consumption is prominent in respect of income, another policy implication of the study would be that the national planners can draw policy lessons from this study. Policymakers need to recognise the variations in food consumption pattern while they design any intervention for improving food and nutritional security of the people in rural areas. Unless the planners notice that there is a significant variation in food consumption pattern across income level, a single intervention would not bring about a desirable effect. As far as the variation in consumption pattern is concerned, there need to be tailored interventions suitable to different group context. In addition, emphasis needs to be given in place for designing nutritional intervention for the poorest of the rural region. Concerned policymakers also need to promote the equitable distribution of income in the economy otherwise a particular segment of the population would always be deprived with respect to food and nutrition. Finally the study reaffirms that the population's consumption behaviour including choice of foods and distribution are most important for the overall food security situation (Murshid et al., 2008).

\section{References}

Ahmed, N., Barnett, I., and Longhurst, R. (2015). Determinants of child undernutrition in Bangladesh literature review. MQSUN report, The Institute of Development Studies (IDS).

Arsenault, J. E., Yakes, E. A., Islam, M. M., Hossain, M. B., Ahmed, T., Hotz, C., Lewis, B., Rahman, A. S., Jamil, K. M., and
Brown, K. H. (2013). Very low adequacy of micronutrient intakes by young children and women in rural Bangladesh is primarily explained by low food intake and limited diversity. The Journal of Nutrition, 143(2), 197-203.

https://doi.org/10.3945/jn.112.169524

BBS. (2011). Household Income and Expenditure Survey 2010. Bangladesh Bureau of Statistics, Ministry of Planning, Government of the People's Republic of Bangladesh.

Bose, M. L., and Dey, M. M. (2007). Food and nutritional security in Bangladesh: Going beyond carbohydrate counts. Agricultural Economics Research Review, 20(482), 203-225.

GoB. (2015). Millennium Development Goals: Bangladesh Progress Report 2015. General Economic Division, Bangladesh Planning Commision, Government of the People's Republic of Bangladesh, Dhaka.

GoB. (2017). Bangladesh Economic Review 2017. Economic Adviser's Wing, Finance Division, Ministry of Finance, Government of the People's Republic of Bangladesh, Dhaka.

Harris-Fry, H., Azad, K., Kuddus, A., Shaha, S., Nahar, B., Hossen, M., Younes, L., Costello, A., and Fottrell, E. (2015). Socioeconomic determinants of household food security and women's dietary diversity in rural Bangladesh: A crosssectional study. Journal of Health, Population and Nutrition, 33(1), 1-12. https://doi.org/10.1186/s41043-015-0022-0

HKI, and JPGSPH. (2014). State of Food Security and Nutrition in Bangladesh 2013. Helen Keller International and James P. Grant School of Public Health, Dhaka.

Hossain, M., Naher, F., and Shahabuddin, Q. (2005). Food security and nutrition in Bangladesh: Progress and determinants. Journal of Agricultural and Development Economics, 2(2), 103-132.

Mishra, V., and Ray, R. (2009). Dietary diversity, food security and undernourishment: The Vietnamese evidence. Asian Economic Journal, 23(2), 225-247. https://doi.org/10.1111/j.14678381.2009.02010.x

Murshid, K. A. S., Khan, M. N. I., Shahabuddin, Q., Yunus, M., Akhter, S., and Chowdhury, O. H. (2008). Determination of Food Availability and Consumption Patterns and Setting up of Nutritional Standard in Bangladesh. Bangladesh Institute of Development Studies.

Nahar, Q. (2013). Desirable Dietary Pattern for Bangladesh. Retrieved from http://www.nfpcsp.org/agridrupal/sites/default/ files/ToR 15- Fial Report BIRDEM.pdf

NIPORT, Mitra and Associates, and ICF International. (2016). Bangladesh Demographic and Health Survey 2014. National Institute of Population Research and Training, Mitra and Associates, Dhaka and ICF International, Maryland.

Rah, J. H., Akhter, N., Semba, R. D., de Pee, S., Bloem, M. W., Campbell, A. A., Moench-Pfanner, R., Sun, K., Badham, J., and Kraemer, K. (2010). Low dietary diversity is a predictor of child stunting in rural Bangladesh. European Journal of Clinical Nutrition, 64(12), 1393-1398. https://doi.org/10.1038/ejen.2010.171

Saha, K. K., Frongillo, E. A., Alam, D. S., Arifeen, S. E., Persson, L. A., and Rasmussen, K. M. (2009). Household food security is associated with growth of infants and young children in rural Bangladesh. Public Health Nutrition, 12(9), 1556-1562. https://doi.org/10.1017/S1368980009004765

Zongrone, A., Winskell, K., and Menon, P. (2012). Infant and young child feeding practices and child undernutrition in Bangladesh: Insights from nationally representative data. Public Health Nutrition, 15(09), 1697-1704. https://doi.org/10.1017/S1368980012001073 